\title{
THE EFFECT OF THE EXCHANGE RATE ON INDUSTRY-LEVEL TRADE FLOWS IN CZECHIA
}

\author{
Jana Šimáková, Daniel Stavárek
}

\section{Introduction}

The relationship between exchange rates and international trade belongs among the topics that have attracted considerable interest in both academic research and policy making. An extensive body of literature has been published, particularly since the collapse of the Bretton Woods system, which brought about floating exchange rates of the major world currencies and increased exchange rate uncertainty. The effects of exchange rate on international trade can be examined from various perspectives. Traditionally, the studies concerning this issue have focused on the effects of exchange rates' variability. More recently, principally due to the emergence of global economic imbalances, the attention in research and policy debates has shifted towards the effects of sustained exchange rate depreciation and exchange rate misalignments. Nevertheless, the global financial crisis and its subsequent developments caused the effects of exchange rate volatility to regain importance. This contemporary research concept is also applied in the present paper as we concurrently address both aspects of exchange rate development.

In theory, the effect of exchange rate levels and their changes can be analyzed in terms of price and volume effects on exports and imports. Because the depreciation of the currency results in the reduction in the price of exports, the demanded quantity for them will increase. At the same time, the price of imports will rise, and their demanded quantity will decrease. A positive effect of currency depreciation on trade balance is, however, conditioned by the validity of the Marshall-Lerner condition, which states that the sum of export and import demand elasticity has to be at least one. This condition is usually not met in the short run. Therefore, the short-run deterioration and long-run improvement of trade balance after depreciation graphically resembles the letter " $\mathrm{J}$ " and is known in literature as the J-curve phenomenon.

A classic theoretical view supported by many studies published throughout the 1970s and 1980s holds that increases in exchange rate variability will have adverse effects on the volume of international trade. They argue that if changes in the exchange rate are unpredictable, it indicates uncertainty about companies' profits and reduces the benefits of international trades. Hence, the main target of attention was the channel through which the uncertainty generated by short-run and long-run volatility is transmitted to the decision to trade, its expected profitability, and eventually the allocation of resources between tradable and non-tradable goods and services [4]. Furthermore, the relationship between exchange rate volatility and the volume of international trade can be affected by many other factors, such as the degree of competition, the role of invoicing currency, the absence of imported inputs, the aversion to risk, the commodity and geographical structure of trade or the availability of exchange rate hedging instruments.

In this paper, we investigate the nature of the relationship between the exchange rate and international trade in Czechia. The Czech economy seems to be attractive and suited for such an analysis for many reasons. Czechia is a small, open economy with intensive involvement in foreign trade activities. The ratio of international trade to GDP has been increasing over time and exceeded $150 \%$ in 2013. A substantial part of Czech trade is done with other EU member countries and, hence, is denominated in the euro. Moreover, the Czech economy is largely owned by foreign investors. The weight of foreign controlled companies in the Czech economy varies between $45 \%$ and $60 \%$, according to the indicator used. Czechia 
has been applying a floating exchange rate regime since 1997, and in November 2013, the exchange rate of Czech koruna vis-à-vis the euro was adopted by the Czech National Bank as a regular monetary policy tool. The Czech National Bank was motivated by the ambition to prevent deflation in an environment of the zero interest rate and impossibility to lower it even further.

Although the aforementioned characteristics have already motivated other researchers to publish several similar studies, our paper extends the research in a new direction. We fully address the criticism of using aggregate international trade data (see e.g. [35]), and this paper represents the first study for Czechia that applies disaggregated data at the industry level. Therefore, the main purpose of the paper is to reveal the effect of exchange rate development on industry level trade flows in the context of the Czech economy. This study contributes to the current evidence by showing differences in the relationship between the exchange rate and international trade across the industries in a small open economy with strong trade connections to the EU and the euro area. The topicality of this research is underlined by the recent devaluation of Czech koruna driven by interventions of the Czech National Bank. Therefore, the findings of this paper can help to assess effects of the devaluation rigorously. To this end, the next section reviews relevant literature published in the examined field. The following section introduces the empirical model and data used in estimation. The next section presents and discusses the empirical results. Finally, the last section makes conducting remarks.

\section{Review of Relevant Literature}

The literature review section is structured in accordance with our research purpose to examine the relationship between the exchange rate and international trade from two viewpoints. First, we review studies that relate the trade volume to the exchange rate level, and second, we focus on papers that analyze the effects of exchange rate volatility on trade balance.

\subsection{Exchange Rate Levels and Trade}

The theoretical assumption that currency depreciation temporarily worsens a country's trade balance and improves it later ( $\mathrm{J}$-curve effect) has not been conclusively validated by empirical research. The findings are mixed and depend on the country (region) and period under estimation and on the data and methodology used. Many studies have even confirmed a negative relationship or no longterm relationship at all. We refer to BahmaniOskooee and Ratha [13] for an excellent indepth review of the J-curve literature. According to Baek [5], the literature concerning the J-curve issue tends to fall into one of the following categories.

- Studies that used aggregate trade data (e.g. [7], [21], [29]).

- Studies that employed disaggregate trade data at a bilateral level (e.g. [42], [1], [14]).

- Studies that used disaggregate trade data at the industry/commodity level (e.g. [9], [11], [10]).

The first-type studies suffer from a substantial aggregation bias of data. Those studies usually employ data on trade balance between a country and the rest of the world along with an effective exchange rate. Furthermore, one needs to construct a proxy for the world income, which can also be partly misleading [35]. The second-generation studies, therefore, use bilateral exchange rates and bilateral trade balance data between a country and its major trading partners. However, these studies still do not address the issue of different responses of trade balance on exchange rates across the industries and/or commodity groups. Hence, the third-type studies, which represent the most recent works, disaggregate the data to the industry level, as well. In other words, a greater availability of more precise data allows researchers to use exchange rates and industry/commodity-level data on a bilateral basis and simultaneously treats exports and imports separately to assess the relationship between exchange rate and trade balance accurately.

Although many studies on the J-curve effect have been published, few of them focus on Central and Eastern European (CEE) countries and Czechia in particular. Bahmani-Oskooee and Kutan [12] is the most comprehensive study of the J-curve phenomenon in emerging Europe. Based on data from 12 countries covering the period 1990-2005, they found empirical support for the J-curve effect in Bulgaria, Croatia and Russia. By contrast, no evidence of the J-curve effect was revealed for Czechia. 
More recently, Nusair [30] applied a similar methodology of autoregressive distributed lag (ARDL) cointegration and a corresponding error correction model on data from 17 emerging and transitioning countries over the period 1991-2012. In empirical estimations, an aggregate trade balance data and effective exchange rates are used. Although the J-curve effect was present in Armenia, Georgia and Ukraine, the Czech economy remained free of the J-curve effect.

Two studies confirmed the existence of some characteristics associated with the J-curve effect on a bilateral basis. Hacker and Hatemi [23] tested the J-curve for Czechia, Hungary and Poland in their bilateral trade with Germany. They came to the conclusion that trade balance deteriorates within a few months after depreciation and then rises to a long-run equilibrium value higher than the initial one. The J-curve effect in bilateral trade between Czechia and Germany was also empirically confirmed by Šimáková [23], who applied a traditional methodology comprised of Johansen's cointegration and error correction model. Moreover, Šimáková [36] also found the J-curve in Czechia's trade with Poland.

On the contrary, Hsing [25] examined the J-curve for the bilateral trade of six CEE countries, including Czechia and the USA, and found no evidence of this effect in any of the analyzed states. This inconsistency can be related to the relatively insignificant share of the USA in the international trade of the CEE countries. For example, during the period 19932013, the USA was the twelfth most prominent trading partner of Czechia with a share of $2.2 \%$. This share is considerably less than Germany, which is the most important trading partner of Czechia with a share of $31.5 \%$.

\subsection{Exchange Rate Volatility and Trade}

The question of whether exchange rate uncertainty reduces incentives to trade internationally has been of permanent research interest, particularly since the early 1970s, when major currencies quit the fixed exchange rate regime and started to flow. A classical model that explains how exchange rate volatility affects trading firms was introduced by Clark [18] and later refined by Hooper and Kohlhagen [24]. The model assumes a small firm in a perfectly competitive market producing a single output entirely for export. The product contains no imported input, and the firm is completely paid in foreign currency with limited access to currency hedging. Therefore, the firm has an open exchange rate exposure, and the uncertainty about future exchange rates is fully reflected in the uncertainty about future revenues in the domestic currency. As a result, the exchange rate volatility reduces the firm's output and export as the firm is forced to curtail its exposure to exchange rate risk. In summary, this basic model establishes a rather negative relationship between exchange rate volatility and international trade.

Although studies published during the 1970s and 1980s broadly support the view of this classical approach, subsequent research inspected the assumptions thoroughly and relaxed them gradually. This paved the way to more sophisticated models with a multi-country and multi-currency environment and diversified firms, in which the relationship between exchange rates, the supply of goods, and the decision to trade became more ambiguous [4]. Some models introduced in the late 1980s and early 1990s focus on hysteresis in global trade and come to the conclusion that the high volatility of exchange rates and the related uncertainty can contribute to the decision to enter or exit international trade in the presence of sunk costs. In this situation, the responsiveness of firms to short-run exchange rate fluctuations would be limited, and firms would prefer a wait-and-see attitude. Some other models overlook the effects of exchange rate volatility on the volume of trade and emphasize the effects on the composition of international trade. In such a model, exchange rate risk reduces net trade, which is the difference between gross trade and intra-industry trade [28].

As is evident from the review of theoretical approaches, there is no consensus among the models on the effects of exchange rate volatility on trade. Furthermore, vast empirical research conducted in support of theoretical models' considerations provides no less ambiguous evidence on this issue. One can illustrate this lack of consensus by the conclusions formulated in Taglioni [38] or Ozturk [31], which hold that if the presumed adverse effect of exchange rate volatility on trade flows exists, it is certainly not large. This finding is shared by Rajan [33], but he discovered that the exchange rate volatility is more likely to reduce international trade if the research focuses on bilateral trade instead of aggregate trade. 
The empirical literature examining the effect of exchange rate volatility on trade in Czechia is even rarer than the literature that examines the effect of exchange rate levels. The effect of exchange rate volatility on trade is often analyzed with a gravity model and an estimation of the respective gravity equation, which is also the case of three papers cited here.

Ferto and Fogarasi [22] explored the effect in a balanced panel of six CEE countries including Czechia over the period 19992008. They focused on trade with agricultural products and found a negative effect of exchange rate volatility on exports when the Pseudo-Maximum-Likelihood estimator method was applied. A similar conclusion is drawn in Šimáková [37], who tested the effect of exchange rate volatility on bilateral trade flows between Czechia and its 17 major trading partners in 1997-2012. Šimáková [37] applied an enhanced methodology compared to Ferto and Fogarasi [22] and used an extended gravity model that controls for other factors likely to determine bilateral trade. The estimation of the panel regression led to the conclusion that a doubling of exchange rate volatility reduces trade by $3 \%$.

In accordance with Šimáková [37], a significant and negative effect of exchange rate volatility on trade was revealed by Babecká Kucharčuková [6]. She alternatively applied static and dynamic versions of the gravity model on a panel dataset that contained 38 trading partners of Czechia from 1999-2008. The magnitude of the exchange rate volatility effect is greater in the dynamic model. A $100 \%$ increase in bilateral exchange rate volatility leads to a decrease in trade of $2.9-3.1 \%$ in the dynamic model (similar to findings of Šimáková [37]) and $0.6-1.2 \%$ in the static model.

In addition to gravity models, the exchange rate volatility effect can be examined by other methods. For instance, Tomanová [41] used a volatility series obtained from a $\mathrm{GARCH}$ model in ARDL cointegration and error correction modelling for bilateral export flows between CEE countries and the euro area over the period 1999-2013. No significant result was found, and the effect of exchange rate volatility turned out to be ambiguous.

\section{Models and Data Specification}

Following recent studies (e.g. [12], [25]) equation (1) is adopted in the empirical modelling of the long-term relationship between exchange rates and trade balance. We apply the cointegration procedure developed by Johansen [26] to avoid the main criticism of early studies, whose results could suffer from a spurious regression problem because of non-stationary data.

$$
\begin{aligned}
& \ln T B_{p . t}=\alpha+\beta \ln Y_{d, t}+\gamma \ln Y_{f, t}+ \\
& +\lambda \ln E R_{f, t}+\varepsilon_{t},
\end{aligned}
$$

where $T B_{p}$ is a measure of the trade balance in time period $t$ defined as the ratio of exports of the Czech Republic to country $f$ over the Czech imports from country $f$ in a selected product group p. $Y_{d}$ is measure of the Czech industrial production (proxy for monthly Czech income) set in index form to make it unit free [8]; $Y_{f}$ is the index of industrial production in trading partner $f$, and $E R_{f}$ is the nominal bilateral exchange rate. The exchange rate is in a direct quotation, i.e., defined in a manner such that an increase reflects a depreciation of the CZK.

$\varepsilon_{t}$ represents an error term.

Because an increase in foreign income $Y_{f}$ is expected to increase the Czech exports to a certain country, an estimate of $\mathrm{Y}$ is expected to be positive. An increase in Czech income $Y_{d}$ is assumed to increase the Czech imports; therefore, an estimate of parameter $\beta$ is expected to be negative. Finally, we expect the parameter $\lambda$ to be positive because the trade balance of an industry should improve due to CZK depreciation.

To test the short-run relationship, a short term dynamic is incorporated into the long-run model. In accordance with Hsing [25], we apply the following modified error correction model (2), where $\alpha, \omega, \beta, \gamma$, and $\lambda$ are parameters of the model, EC is the disequilibrium term and $\vartheta_{k} E C_{t-1}$ represents the error correction mechanism:

$$
\begin{aligned}
& \Delta \ln T B_{p, t}=\alpha+\sum_{k=1}^{n} \omega_{k} \Delta \ln T B_{t-k}+ \\
& +\sum_{k=1}^{n} \beta_{k} \Delta \ln Y_{d, t-k}+\sum_{k=1}^{n} \gamma_{k} \Delta \ln Y_{f, t-k}+ \\
& +\sum_{k=1}^{n} \lambda_{k} \Delta \ln E R_{f, t-k}+\vartheta_{k} E C_{t-1}+\varepsilon_{t}
\end{aligned}
$$

To estimate the effect of exchange rate volatility on foreign trade, we apply a gravity 
model. A frequent criticism of this approach for insufficient theoretical foundations has been eliminated in recent years. The model has a lineage that goes back to Tinbergen [40] and Pöyhönen [32], who specified the gravity model equation as follows (3):

$$
X_{d f}=\delta \frac{Y_{d}^{\beta_{1}} Y_{f}^{\beta_{2}}}{D_{d, f}^{\theta}}
$$

where $\delta, \beta_{1(2)}$ and $\theta$ are the parameters of the modified equation, $X_{d f}$ is the bilateral trade between countries, and $D_{d f}$ is the distance between these two countries. Trade in the gravity equation is predicted to be a positive function of income (because countries with larger economies tends to trade more in absolute terms) and a negative function of distance. According to Arvas [3], the distance can be a proxy for transport costs and an indicator of the time elapsed during shipment; it can be correlated with the cost of searching for trading opportunities and considered a proxy for culture differences connected to different consumer patterns.

The basic gravity equation is frequently extended to incorporate other factors that stimulate or reduce bilateral trade flows. One of the most frequently used factors is the population size of the respective countries. Generally, the coefficient for a country's population is expected to be positive because a larger market in the recipient country is expected to demand more goods, and the population of the export country is expected to be able to supply more as the population grows in size. Recent models also include many dummy variables that should have an effect on transaction costs. For example, common borders, languages and memberships in custom unions are supposed to decrease transaction costs and promote trade [2]. For the purpose of this paper, we incorporate exchange rate volatility and the existence of a common border into the model. Regarding methodology, we follow Tichý [39] and Baldwin et al. [16] and employ the following augmented gravity equation (4):

$$
\begin{aligned}
& \ln X_{p, d f}=\alpha+\beta_{1} \ln Y_{d}+\beta_{2} \ln Y_{f}+ \\
& +\beta_{3} \ln P O P_{d}+\beta_{4} \ln P O P_{f}+\beta_{5} \ln D_{d f}+ \\
& +\beta_{6} \ln V(E R)_{f}+\beta_{7} \ln C B_{d f}+u_{i j},
\end{aligned}
$$

where $P O P_{d(f)}$ stands for the population of country $d(f)$ participating in bilateral trade and dummy variable $C B_{d f}$ represents a common border (it equals 1 if the trading partner shares a common border with a domestic country and 0 if not), $V(E R)_{f}$ is the exchange rate volatility, $\alpha$ and $\beta_{k}$ are the unknown parameters of the model, and $u_{i j}$ is the error term. $X_{p}$ represents the total trade turnover between the pair of countries in an individual product group.

To measure the exchange rate volatility, we used the GARCH model in following form (5):

$$
\sigma_{t}^{2}=\alpha_{0}+\sum_{i=1}^{m} \alpha_{i} e_{t-i}^{2}+\sum_{j=1}^{s} \beta_{j} \sigma_{t-j}^{2},
$$

where $\sigma_{t}^{2}$ is the conditional variance, parameter $\alpha_{0}>0$ and the constraints $\alpha_{i} \geq 0$, $\beta_{j} \geq 0$ are needed to ensure $\sigma_{t}^{2}$ is positive [17]. The variance of the disturbance term for each period is modelled as a function of the errors in the previous periods.

As Arvas [3] states, standard gravity models usually employ cross-sectional data to estimate trade patterns in a given year, or averaged data. We employ a panel data regression to avoid the risk of choosing an unrepresentative year and to monitor unobservable individual effects between trading partners. This can provide additional insight into trading relationships. In addition, the use of panel data is particularly suggested for estimating the relationship between international trade and exchange rate volatility.

Before estimating ordinary least squares regression on panel data, it is necessary to determine dataset effects as random or fixed. Fixed effects are present when the heterogeneity in the model is unobservable but correlated with any variable included in model. Per contra, the heterogeneity in random effects is also unobservable, but it is not correlated with any other variable. In this case, we follow Tichý [39] and use the Breusch-Pagan Langrage multiplier test. We calculated the test criteria from equation (6), where $T$ is the length of time series, $n$ is the number of units in the crosssectional dimension, and $e_{i t}$ is a residual term.

$$
L M=\frac{n T}{2(T-1)}\left[\frac{\sum_{i=1}^{n}\left(\sum_{t=1}^{T} e_{n}\right)^{2}}{\sum_{i=1}^{n} \sum_{t=1}^{T} e_{i t}^{2}}-1\right]^{2}
$$


All time series used for estimation are on a monthly frequency and cover the period from 1993 to 2013. The data of industrial production and nominal bilateral exchange rates were obtained from the OECD iLibrary statistical database. The data of import and export flows were obtained from the Czech Statistical Office. The product groups used in estimations are determined on the basis of SITC classification:

- T0: Food and live animals;

- T1: Beverages and tobacco;

- T2: Crude materials, inedible, except fuels;

- T3: Mineral fuels, lubricants and related materials;

- T4: Animal and vegetable oils, fats and waxes;

- T5: Chemicals and related products;

- T6: Manufactured goods;

- T7: Machinery and transport equipment;

- T8: Miscellaneous manufactured articles; and

- T9: Commodities and transactions not classified elsewhere in the SITC.
Table 1 shows the average share of individual product categories on Czechia's total international trade during the period 1993-2013. Table 1 also includes percentage changes of the product groups' shares from 1993 to 2013. Almost half of total trade falls into product category $\mathrm{T} 7$, and two more product groups (T6 and T8) represent an additional $20 \%$ and $10 \%$ of international trade, respectively.

The time series for the population were acquired from Eurostat. The data on the distance between Czechia and its trading partners were taken from the GeoDist database. The bilateral distances are measured using city-level data. The capital city is considered to be the economic center in all trading countries included in the estimations.

\section{Empirical Analysis and Findings}

In the empirical estimation, we work with the six largest trading partners of Czechia: Austria (AT), Germany (DE), France (FR), Italy (IT), Poland (PL), and Slovakia (SK). Their shares on Czechia's total

Tab. 1: Commodity structure of Czechia's international trade (in \%, 1993-2013)

\begin{tabular}{l|r|r|r|r|r|r|r|r|r|r} 
& \multicolumn{1}{|c|}{ T0 } & \multicolumn{1}{c|}{ T1 } & \multicolumn{1}{c|}{ T2 } & \multicolumn{1}{c|}{ T3 } & \multicolumn{1}{c|}{ T4 } & \multicolumn{1}{c|}{ T5 } & \multicolumn{1}{c|}{ T6 } & \multicolumn{1}{c}{ T7 } & \multicolumn{1}{c}{ T8 } & \multicolumn{1}{c}{ T9 } \\
\hline Share & 3.95 & 0.66 & 2.88 & 6.14 & 0.19 & 8.59 & 19.61 & 46.49 & 10.85 & 0.63 \\
\hline Change & -31.76 & -38.13 & -100.18 & -26.27 & -13.25 & -19.54 & -23.42 & 55.12 & -9.37 & -77.58 \\
\hline
\end{tabular}

Source: authors' calculations

international trade volume are presented in Table 2 in the row labeled TT. Furthermore, we report the shares of these countries on international trade in each of the product categories.

It is evident from the reported indices that Germany is by far the most important trading partner of Czechia with an average share of $31.47 \%$ of the total trade. Moreover, the Germany's share has been increasing over time. Slovakia and Austria are Czechia's second and third largest partners with shares of $8.62 \%$ and $4.96 \%$, respectively. However, both countries lost a substantial part of trade during the period 1993-2013. The shares of the remaining partners are similar to that of Austria and oscillate between $4 \%$ and $5 \%$. Although the shares of Poland and France on Czechia's trade increased over the period analyzed, Italy's share dropped by almost $23 \%$.
The dominant position of Germany in the total trade is also mirrored in the majority of the product categories. The only exceptions are groups T1 and T3 in which Slovakia takes over the position of major trading partner. Austria shows an above-average share in the category T2 (12\%), Italy excels in the T1 group (9\%), and Poland trades intensively with Czechia in groups T0 and T4 (10-11\%). There is no apparent specialization of France; its share in any product category does not significantly surpass the share of total trade.

One can observe several extraordinary changes and shifts in Czechia's international trade structure. For example, the share of Poland of trade with T4 products increased by $1,843 \%$ from 1993 to 2013 , and its share in the T0 category increased by $490 \%$. Furthermore, France's share in trade with $\mathrm{T} 1$ goods raised 
by $543 \%$, and Italy's share in the same product category increased by $453 \%$.

Logarithmic transformation was performed to reduce skewedness and heteroscedasticity and to stabilize variability. The stability of regressors is needed in empirical estimation. The integration of time series was determined by the augmented Dickey-Fuller test. Each individual time series was tested for the presence of unit roots, and the first-difference stationarity was found for all variables.

Because the choice of lag orders of the variables in the vector error correction model specification can have a significant effect on the inferences drawn from the model, we sequentially determined the appropriate lag length for each variable. The literature typically shows lags centered around two years for many countries, but the exact number can differ across the trading partners due to the different character and elasticity of trading goods and time lags in the consumers' search for acceptable, cheaper alternatives [4].

The optimal lags for each estimated trading partner within different product groups determined on the basis of Schwarz information criterion are reported in Table 3. In the same table, one can see results of the Johansen cointegration test on the number of existing cointegration equations. The product groups T4 and T9 were excluded from the analysis due to data inconsistency.

As observed from Table 3, the lag structure differs more across different product categories than across different trading partners. In general, higher lags are typical for groups of manufactured goods, machinery and transport equipment and miscellaneous manufactured articles. These categories of goods are supposed to be purchased under long-term contracts, and it usually takes more time to adapt to new price conditions.

We run 48 cointegration estimations (trade in 8 product groups with 6 countries) but did not reveal cointegration equations in all cases. No long-term relationship with exchange rate development was found, particularly for product groups T3 and T6 traded with Austria, T6 traded with Italy and T8 with France. As a next step, we proceeded with assessing the long-term coefficient estimates for the models with evidence of a cointegrating relationship. Detailed results can be observed in Table 4.

The theoretical expectations of the positive effect of foreign income and the exchange rate and the negative effect of domestic income on trade balance are not convincingly confirmed across the dataset. The expected signs were revealed for $59 \%$ of coefficients of domestic income and foreign income and for $66 \%$ of

\begin{tabular}{|c|c|c|c|c|c|c|c|c|c|c|c|c|}
\hline \multirow[t]{3}{*}{ Tab. } & \multicolumn{12}{|c|}{$\begin{array}{l}\text { Territorial and commodity structure of Czechia's international trade } \\
\text { (in \%, 1993-2013) }\end{array}$} \\
\hline & \multicolumn{2}{|r|}{1} & \multicolumn{2}{|c|}{$\mathrm{DE}$} & \multicolumn{2}{|c|}{ FR } & \multicolumn{2}{|c|}{ IT } & \multicolumn{2}{|c|}{$\mathrm{PL}$} & \multicolumn{2}{|c|}{ SK } \\
\hline & $\mu$ & $\Delta$ & $\mu$ & $\Delta$ & $\mu$ & $\Delta$ & $\mu$ & $\Delta$ & $\mu$ & $\Delta$ & $\mu$ & $\Delta$ \\
\hline $\mathrm{TT}$ & 4.96 & -44.47 & 31.47 & 11.16 & 4.12 & 65.28 & 4.37 & -22.98 & 4.87 & 152.25 & 8.62 & -60.27 \\
\hline TO & 4.19 & 19.11 & 20.27 & 22.36 & 3.50 & 69.69 & 4.1 & 54.4 & 10.13 & 490.51 & 15.18 & $\begin{array}{l}-16.67 \\
\end{array}$ \\
\hline $\mathrm{T} 1$ & 3.72 & -18.61 & 12.82 & -4.17 & 3.31 & 542.82 & 8.98 & 452.8 & 5.76 & 152.20 & 23.94 & -55.44 \\
\hline $\mathrm{T} 2$ & 12.00 & -32.97 & 25.60 & -11.32 & 1.90 & 11.51 & 4.99 & 1.42 & 5.65 & 169.68 & 8.13 & -16.93 \\
\hline T3 & 8.40 & -28.89 & 14.32 & 75.20 & 0.26 & 140.26 & 0.49 & -89.75 & 7.37 & 61.31 & 14.59 & -2.63 \\
\hline $\mathrm{T4}$ & 5.92 & 30.95 & 29.30 & -59.81 & 1.22 & 33.48 & 2. & 10.27 & 10.74 & 1843.2 & 19.10 & -25.61 \\
\hline T5 & 4.39 & -49.04 & 28.17 & 12.17 & 5.12 & 22.44 & 5.20 & -29.67 & 6.87 & 69.03 & 10.73 & -69.37 \\
\hline T6 & 5.48 & -25.97 & 33.86 & 13.90 & 3.36 & 70.73 & 5.24 & -12.16 & 6.82 & 246.63 & 1.33 & -61.51 \\
\hline $\mathrm{T7}$ & 3.82 & -57.47 & 34.56 & 2.10 & 5.30 & 67.14 & 4.19 & -30.98 & 2.93 & 163.88 & 5.56 & -68.02 \\
\hline T8 & 5.23 & -38.92 & 35.15 & -3.89 & 3.17 & 29.11 & 4.85 & -32.37 & 4.13 & 227.59 & 6.93 & -64.30 \\
\hline T9 & 6.84 & 166.60 & 35.69 & 58.28 & 1.62 & -81.49 & 2.49 & 80.40 & 3.61 & 516.70 & 12.80 & 15.19 \\
\hline
\end{tabular}

Note: $\mu$ is the average share and $\Delta$ is the change of the share over the sample period 
Tab. 3: Number of lags and cointegration equations

\begin{tabular}{|c|c|c|c|c|c|c|c|c|c|c|c|c|}
\hline & \multicolumn{2}{|c|}{ AT } & \multicolumn{2}{|c|}{$\mathrm{DE}$} & \multicolumn{2}{|c|}{ FR } & \multicolumn{2}{|c|}{ IT } & \multicolumn{2}{|c|}{ PL } & \multicolumn{2}{|c|}{ SK } \\
\hline & lags & equat. & lags & equat. & lags & equat. & lags & equat. & lags & equat. & lags & equat. \\
\hline TO & 3 & 1 & 4 & 2 & 4 & 1 & 4 & 2 & 2 & 2 & 2 & 1 \\
\hline $\mathrm{T1}$ & 3 & 1 & 4 & 1 & 2 & 1 & 4 & 1 & 2 & 1 & 2 & 1 \\
\hline $\mathrm{T} 2$ & 3 & 1 & 4 & 1 & 4 & 1 & 4 & 1 & 2 & 2 & 2 & 1 \\
\hline T3 & 3 & 0 & 5 & 1 & 5 & 1 & 4 & 1 & 2 & 1 & 2 & 1 \\
\hline T5 & 3 & 1 & 4 & 1 & 5 & 1 & 13 & 1 & 2 & 1 & 1 & 1 \\
\hline T6 & 13 & 0 & 13 & 1 & 13 & 1 & 13 & 0 & 2 & 2 & 17 & 2 \\
\hline T7 & 13 & 1 & 13 & 2 & 13 & 1 & 15 & 1 & 2 & 1 & 17 & 2 \\
\hline T8 & 13 & 1 & 13 & 1 & 15 & 0 & 15 & 1 & 2 & 1 & 12 & 1 \\
\hline
\end{tabular}

Source: authors' calculations

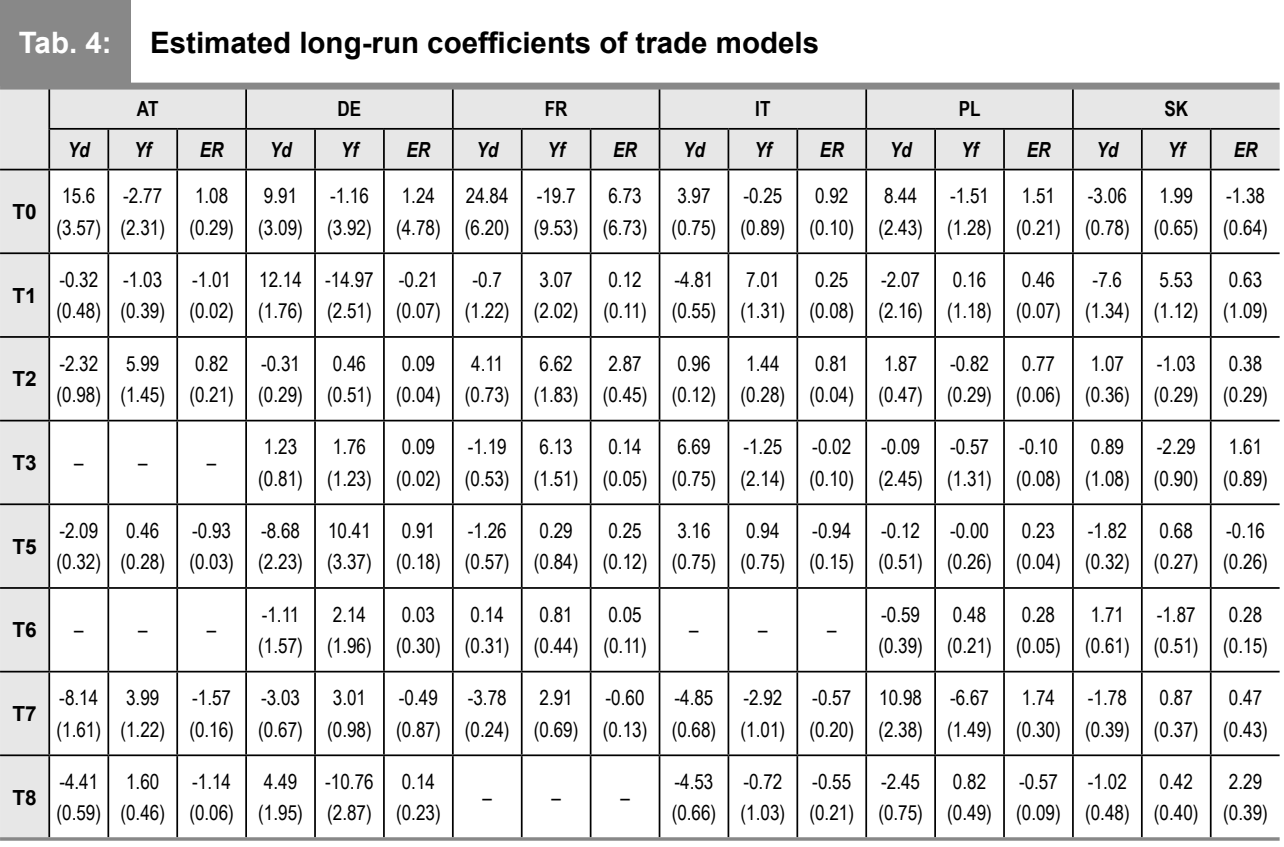

Note: Standard errors in parentheses

Source: authors' calculations

exchange rate coefficients. From the countrylevel perspective, the highest concordance with theoretical assumptions was found in trade with France $(76 \%$ of coefficient signs match the expectations). By contrast, the lowest conformity with theory was revealed in trade with Italy (only $43 \%$ of coefficients correspond with expectations). Germany, as the largest trading partner of Czechia, demonstrates a $62 \%$ conformity with theoretical assumptions. On the industry level, trade with T6, T1 and T5 products seems to be very close to the theory, with more than $70 \%$ of coefficients signs in accordance with expectations. On the contrary, international trade with products falling into product groups T0 and T3 demonstrates very low conformity with expectations, with only $39 \%$ and $46 \%$ of correctly signed coefficients. 
Although a positive effect of CZK depreciation on trade balance prevails in the results obtained, it can be observed in Table 4 that many coefficient for the largest trading partners and the most important product groups suggest an opposite effect. For instance, the depreciation of CZK worsens the trade balance with Germany in group T7. Because the T7 group accounts for $46.5 \%$ of Czechia's international trade and
Germany's share in this product group is $34.6 \%$, the negative effect of CZK depreciation relates to $16 \%$ of Czechia's total international trade. A similar conclusion can be drawn for $\mathrm{T} 7$ trade with Austria, France and Italy or for T8 trade with Austria, Italy and Poland. All the mentioned cases of the opposite-than-expected effect of CZK depreciation jointly comprise $23.5 \%$ of total trade, which cannot be considered negligible.

\section{Tab. 5: Estimated short-run coefficients of exchange rate level - Part 1}

\begin{tabular}{|c|c|c|c|c|c|c|c|c|c|c|c|c|c|c|c|c|c|}
\hline & $\Delta 1$ & $\Delta 2$ & $\Delta 3$ & $\Delta 4$ & $\Delta 5$ & $\Delta 6$ & $\Delta 7$ & $\Delta 8$ & $\Delta 9$ & $\Delta 10$ & $\Delta 11$ & $\Delta 12$ & $\Delta 13$ & $\Delta 14$ & $\Delta 15$ & $\Delta 16$ & $\Delta 17$ \\
\hline \multicolumn{18}{|l|}{ TO } \\
\hline AT & 0.13 & -0.02 & 0.08 & & & & & & & & & & & & & & \\
\hline $\mathrm{DE}$ & -0.01 & $0.05^{\mathrm{a}}$ & 0.02 & 0.01 & & & & & & & & & & & & & \\
\hline $\mathrm{FR}$ & 0.11 & -0.05 & -0.02 & 0.04 & & & & & & & & & & & & & \\
\hline IT & 0.07 & 0.03 & -0.05 & -0.02 & & & & & & & & & & & & & \\
\hline PL & -0.07 & -0.01 & & & & & & & & & & & & & & & \\
\hline SK & 0.02 & -0.01 & & & & & & & & & & & & & & & \\
\hline \multicolumn{18}{|l|}{$\mathrm{T} 1$} \\
\hline AT & 0.19 & 0.08 & -0.14 & & & & & & & & & & & & & & \\
\hline $\mathrm{DE}$ & -0.04 & -0.08 & $-0.08^{\mathrm{a}}$ & $-0.06^{a}$ & & & & & & & & & & & & & \\
\hline FR & -0.05 & 0.01 & & & & & & & & & & & & & & & \\
\hline IT & 0.04 & $-0.14^{a}$ & $-0.15^{\mathrm{a}}$ & -0.09 & & & & & & & & & & & & & \\
\hline $\mathrm{PL}$ & 0.20 & 0.20 & & & & & & & & & & & & & & & \\
\hline SK & $-0.19^{b}$ & -0.05 & & & & & & & & & & & & & & & \\
\hline \multicolumn{18}{|l|}{ T2 } \\
\hline AT & 0.23 & 0.19 & 0.02 & & & & & & & & & & & & & & \\
\hline $\mathrm{DE}$ & 0.07 & $0.05^{\mathrm{a}}$ & $0.07^{\mathrm{a}}$ & 0.02 & & & & & & & & & & & & & \\
\hline FR & 0.01 & 0.01 & -0.07 & -0.01 & & & & & & & & & & & & & \\
\hline IT & 0.08 & 0.08 & -0.07 & $0.12^{\mathrm{a}}$ & & & & & & & & & & & & & \\
\hline PL & -0.09 & 0.01 & & & & & & & & & & & & & & & \\
\hline SK & -0.01 & 0.02 & & & & & & & & & & & & & & & \\
\hline \multicolumn{18}{|l|}{ T3 } \\
\hline $\mathrm{DE}$ & $0.04^{\mathrm{a}}$ & $0.03^{\mathrm{a}}$ & $0.02^{\mathrm{a}}$ & $0.04^{\mathrm{a}}$ & $0.04^{\mathrm{a}}$ & & & & & & & & & & & & \\
\hline FR & $0.14^{b}$ & 0.10 & $0.13^{b}$ & $0.42^{b}$ & $-0.09^{b}$ & & & & & & & & & & & & \\
\hline IT & -0.01 & -0.11 & -0.07 & -0.11 & & & & & & & & & & & & & \\
\hline PL & 0.03 & $-0.01^{a}$ & & & & & & & & & & & & & & & \\
\hline SK & $0.06^{\mathrm{a}}$ & 0.01 & & & & & & & & & & & & & & & \\
\hline \multicolumn{18}{|l|}{ T5 } \\
\hline AT & -0.20 & -0.14 & 0.06 & & & & & & & & & & & & & & \\
\hline $\mathrm{DE}$ & -0.01 & -0.08 & -0.01 & -0.01 & & & & & & & & & & & & & \\
\hline FR & 0.23 & 0.39 & 0.13 & -0.34 & -0.02 & & & & & & & & & & & & \\
\hline IT & $-0.22^{b}$ & $-0.18^{a}$ & $-0.17^{a}$ & $-0.13^{b}$ & $-0.17^{b}$ & -0.08 & $-0.11^{b}$ & -0.05 & $-0.12^{b}$ & $-0.19^{\mathrm{a}}$ & $-0.18^{a}$ & -0.00 & $-0.11^{b}$ & & & & \\
\hline $\mathrm{PL}$ & $-0.14^{b}$ & -0.04 & & & & & & & & & & & & & & & \\
\hline SK & -0.05 & & & & & & & & & & & & & & & & \\
\hline
\end{tabular}




\section{Tab. 5: Estimated short-run coefficients of exchange rate level - Part 2}

\begin{tabular}{|c|c|c|c|c|c|c|c|c|c|c|c|c|c|c|c|c|c|}
\hline & $\Delta 1$ & $\Delta 2$ & $\Delta 3$ & $\Delta 4$ & $\Delta 5$ & $\Delta 6$ & $\Delta 7$ & $\Delta 8$ & $\Delta 9$ & $\Delta 10$ & $\Delta 11$ & $\Delta 12$ & $\Delta 13$ & $\Delta 14$ & $\Delta 15$ & $\Delta 16$ & $\Delta 17$ \\
\hline \multicolumn{18}{|l|}{ T6 } \\
\hline $\mathrm{DE}$ & -0.01 & -0.02 & 0.04 & 0.02 & -0.00 & 0.01 & 0.04 & -0.00 & 0.00 & 0.06 & 0.04 & $0.05^{b}$ & 0.03 & & & & \\
\hline FR & 0.04 & -0.06 & -0.05 & 0.13 & 0.19 & 0.15 & 0.19 & -0.06 & 0.03 & 0.05 & 0.06 & 0.12 & 0.26 & & & & \\
\hline $\mathrm{PL}$ & -0.03 & -0.01 & & & & & & & & & & & & & & & \\
\hline SK & 0.38 & -0.49 & 0.56 & $-0.11^{a}$ & $-0.74^{a}$ & 1.00 & $-0.27^{b}$ & -0.24 & 0.23 & -0.31 & 0.43 & -0.18 & $-0.69^{b}$ & -0.93 & 0.02 & -0.79 & -0.23 \\
\hline \multicolumn{18}{|l|}{$\mathrm{T7}$} \\
\hline AT & 0.16 & 0.25 & 0.01 & -0.01 & -0.15 & -0.22 & -0.22 & -0.17 & -0.13 & -0.17 & $-0.33^{b}$ & -0.16 & 0.12 & & & & \\
\hline $\mathrm{DE}$ & 0.03 & 0.03 & 0.01 & 0.02 & 0.01 & -0.03 & -0.02 & -0.00 & 0.01 & 0.00 & $0.04^{b}$ & $0.04 b$ & -0.01 & & & & \\
\hline FR & -0.08 & $-0.03^{\mathrm{a}}$ & 0.11 & 0.10 & 0.13 & -0.01 & 0.04 & 0.05 & 0.08 & 0.03 & 0.18 & 0.15 & 0.20 & & & & \\
\hline IT & -0.08 & $-0.32^{b}$ & $-0.22^{\mathrm{a}}$ & -0.11 & $-0.20^{b}$ & $-0.17^{b}$ & 0.01 & 0.01 & 0.02 & -0.03 & -0.07 & 0.06 & -0.06 & -0.03 & -0.07 & & \\
\hline PL & 0.05 & -0.01 & & & & & & & & & & & & & & & \\
\hline SK & 0.07 & 0.14 & 0.09 & -0.04 & -0.07 & 0.04 & 0.08 & 0.08 & 0.07 & 0.24 & 0.20 & 0.18 & 0.22 & 0.04 & 0.14 & $0.18^{b}$ & 0.12 \\
\hline \multicolumn{18}{|l|}{ T8 } \\
\hline AT & 0.30 & 0.33 & 0.09 & -0.01 & 0.15 & 0.11 & 0.09 & -0.06 & -0.12 & -0.17 & -0.11 & 0.06 & 0.13 & & & & \\
\hline $\mathrm{DE}$ & 0.07 & 0.07 & 0.06 & 0.04 & 0.03 & 0.01 & 0.05 & 0.04 & 0.03 & 0.06 & $0.05^{\mathrm{a}}$ & $0.06^{\mathrm{a}}$ & 0.03 & & & & \\
\hline IT & -0.00 & $-0.18^{b}$ & -0.23 & $-0.07^{b}$ & $-0.19^{b}$ & $-0.12^{b}$ & -0.21 & -0.07 & -0.04 & $-0.01^{a}$ & 0.00 & 0.20 & 0.00 & 0.00 & 0.01 & & \\
\hline $\mathrm{PL}$ & 0.06 & -0.01 & & & & & & & & & & & & & & & \\
\hline SK & -1.48 & -0.45 & 0.21 & -0.13 & -0.20 & 1.05 & -0.37 & -1.49 & 0.15 & -0.05 & -0.77 & 0.54 & & & & & \\
\hline
\end{tabular}

Note: ${ }^{a},{ }^{b}$ denote significance level at the $5 \%$ and $10 \%$ level, respectively.

An ambiguous effect of exchange rate can be explained by several characteristics of Czechia's international trade. Czechia's exports and entire economy rely extremely heavily on imports. The share of imported goods on GDP was $66 \%$ in 2012, which put Czechia at fifth place in the EU (the EU average is $32 \%$ ). Only $27 \%$ of total imports are used for final consumption. The remaining $73 \%$ of imports represent semi-finished products or goods used in further production processes. In other words, a $100 \mathrm{CZK}$ of new value added produced in the Czech economy in 2012 required $73 \mathrm{CZK}$ of imported goods and services. For comparison, the demand for import was only 60 CZK per 100 CZK of new value added in 2002 (an increase of $21.5 \%$ ).

Another typical feature of the Czech economy is a strong presence of foreign direct investment (see e.g. [34]). Many foreignowned companies with production facilities in Czechia belong to multinational corporations with operations in various countries. Therefore, they are also involved in intensive export/import transactions within the multinational company or with related enterprises. Kiss and Schuszter
[27] also discuss the pros and cons of corporate financing through loans in foreign currencies. Hence, all the mentioned attributes lead to the fact that a substantial part of international trade in Czechia is associated with natural hedging. Čadek et al. [19] analyzed the hedging behavior of Czech exporting firms and found that most exporters use natural hedging; i.e., they balance incoming and outgoing payments in foreign currency and foreign currency assets and liabilities. In 2009, almost $60 \%$ of hedged exports were hedged using natural hedging, and the rest were covered primarily by financial derivatives. Čadek et al. [19] also revealed that $88 \%$ of exports in 2009 were hedged by any type of hedging strategy. Moreover, Czech exporters typically use hedging instruments with a maturity of between three months and one year. In summary, one can identify many factors in the Czech economy that cause the pass-through of exchange rate changes into the trade balance to be weaker and less straightforward than the theory suggests.

As indicated before, the short-run effects of depreciation are reflected in the coefficient 
estimates obtained for the lagged value of the first differenced exchange rate variable (Tab. 5). The J-curve approach allows us to distinguish the short-run effects from the long-run effects. The traditional J-curve is confirmed if the estimate of the coefficient for the exchange rate is significantly negative at lower lags and is followed by a significantly positive coefficient at longer lags. Simultaneously, the J-curve can be represented as negative short-run coefficients, followed by a positive long-run coefficient.

In this study, only some short-term coefficients are statistically significant. The most statistically significant coefficients are revealed for trade with Germany. These coefficients show a positive short-term relationship between exchange rate and trade balance in T2, T3 and T8 product groups. On the contrary, significantly negative coefficients can be found for groups T1, T5, T7 and T8 traded with Italy and in T6 traded with Slovakia. The short-run significant negative coefficient in T1 traded with Italy and T6 traded with Slovakia are associated with a positive long-run relationship and jointly confirm the only examples of the J-curve pattern found in this paper. For other cases examined, the $\mathrm{J}$-curve phenomenon is not supported by the estimated coefficients of exchange rates. These findings are similar to the conclusions of other studies analyzing Czechia (e.g. [12], [30]).

\section{Tab. 6: Estimated coefficients of gravity model}

\begin{tabular}{c|c|c|c|c|c|c|c|c} 
& T0 & T1 & T2 & T3 & T5 & T6 & T7 & T8 \\
\hline \multirow{2}{*}{$\mathbf{Y}_{\mathbf{d}}$} & 2.14 & 3.61 & 1.51 & 1.74 & 1.98 & 2.06 & 2.06 & 2.06 \\
& $(0.06)$ & $(0.12)$ & $(0.06)$ & $(0.11)$ & $(0.04)$ & $(0.05)$ & $(0.06)$ & $(0.07)$ \\
\hline \multirow{2}{*}{$\mathbf{Y}_{\mathbf{f}}$} & 0.76 & 2.61 & 1.67 & 0.66 & 0.71 & 1.42 & 0.93 & 0.95 \\
& $(0.05)$ & $(0.09)$ & $(0.05)$ & $(0.09)$ & $(0.03)$ & $(0.04)$ & $(0.05)$ & $(0.06)$ \\
\hline \multirow{2}{*}{$\mathbf{P O P}_{\mathbf{d}}$} & -0.29 & -1.78 & -2.42 & -1.53 & 0.24 & -1.46 & 1.45 & 1.54 \\
& $(0.16)$ & $(0.30)$ & $(0.16)$ & $(0.29)$ & $(0.09)$ & $(0.12)$ & $(0.17)$ & $(0.13)$ \\
\hline \multirow{2}{*}{$\mathbf{P O P}_{\mathbf{f}}$} & 1.13 & -0.46 & -1.55 & -0.50 & 1.27 & 0.01 & 3.35 & 3.14 \\
& $(0.12)$ & $(0.23)$ & $(0.13)$ & $(0.22)$ & $(0.07)$ & $(0.09)$ & $(0.14)$ & $(0.13)$ \\
\hline \multirow{2}{*}{$\mathbf{V}(\mathbf{E R})_{\mathbf{f}}$} & -0.46 & 0.72 & 1.75 & 0.54 & 0.24 & 0.93 & -0.11 & -0.20 \\
& $(0.08)$ & $(0.15)$ & $(0.08)$ & $(0.14)$ & $(0.05)$ & $(0.06)$ & $(0.08)$ & $(0.11)$ \\
\hline \multirow{2}{*}{$\mathbf{D}_{\text {df }}$} & -1.29 & -0.43 & 4.88 & 2.69 & -2.19 & 1.48 & -7.14 & -6.21 \\
& $(0.37)$ & $(0.69)$ & $(0.38)$ & $(0.66)$ & $(0.22)$ & $(0.28)$ & $(0.41)$ & $(0.32)$ \\
\hline \multirow{2}{*}{$\mathbf{C B}_{\text {df }}$} & 0.65 & 1.31 & 4.87 & 5.23 & 0.15 & 2.74 & -2.74 & -2.33 \\
& $(0.22)$ & $(0.42)$ & $(0.23)$ & $(0.40)$ & $(0.13)$ & $(0.17)$ & $(0.25)$ & $(0.14)$ \\
\hline
\end{tabular}

Note: Standard errors in parentheses

In the second part of the empirical section, we estimated the extended gravity model to examine the effect of exchange rate volatility on foreign trade. We apply the least squares method for panel data in the model estimation. The dependent variable in the model is the total trade turnover between Czechia and its selected trading partners within individual product groups. We have included 6 crosssections (trading partners) and 251 periods (monthly data from January 1993 to November 2013). Therefore, we yielded in total 1,506 panel observations for each product group. The results of the estimation are summarized in
Table 6. Most of the parameters obtained from the panel regressions are highly significant. The few exceptions are coefficients $D_{d f}(\mathrm{~T} 1)$, $C B_{d f}$ (T5) and $P O P_{f}$ (T6). Across the product groups, we can observe a positive effect of both domestic and foreign income on foreign trade. Notably, the estimated influence of the domestic effect seems to be generally larger than the effect of foreign income (except the T2 product group). The estimated effect of population size is not as uniform. The theoretical expectations of the positive effect of the population size are empirically confirmed only for product groups T5, T7 and T8. For the same commodities, 
we revealed a negative effect of the distance between economic centers on trade turnover. However, a common border decreases the trade turnover in product categories T7 and T8.

Regarding the effect of exchange rate volatility, our results are not completely in conformity with existing literature. Whereas Šimáková [37] and Babecká Kucharčuková [6] apply aggregate data and validate the theoretical assumption of the negative effect of exchange rate volatility on Czech foreign trade, the present study with disaggregated data discovers a variable effect of volatility depending on the product group. A negative effect on trade was detected in the groups T0, $\mathrm{T} 7$ and T8. These groups jointly account for $61.3 \%$ of Czechia's foreign trade. By contrast, a higher exchange rate volatility seems to increase foreign trade turnover in T1, T2, T3, and T5 product categories $(18.3 \%$ of total foreign trade). Such diversity in the estimated coefficients of exchange rate volatility can also be found in papers applying disaggregated data to countries other than Czechia [15], [10].

\section{Conclusions}

The paper sheds some new light on the relationship between exchange rates and foreign trade in Czechia. We particularly examine the effect of exchange rate levels on trade balance and the effect of exchange rate volatility on foreign trade turnover. Whereas the former issue is analyzed by cointegration and vector error correction model, the latter is examined by the extended gravity model with panel data. Because the present paper represents the first study to focus on Czechia and employ disaggregated industry-level data of bilateral trade with largest trading partners, the greatest contribution of this study are the more detailed results.

We found that the effect of the exchange rate on trade balance is ambiguous. Although most of the estimations indicate that the depreciation of Czech koruna improves the trade balance, the empirical findings for the largest trading partners and most important product groups show an opposite effect. As the most typical example of the negative effect of koruna depreciation, one can mention the trading of machinery and transport equipment with Germany, Austria or France. A similar conclusion can also be drawn for the product group of miscellaneous manufactured articles.
The J-curve effect, i.e., the temporary worsening and later improvement of trade balance after depreciation, was empirically confirmed only for the trading of beverages and tobacco with Italy and for the trading of manufactured goods with Slovakia. The theoretical assumptions are not entirely met even in the case of the effect of exchange rate volatility on foreign trade. We found evidence that higher volatility increases the turnover of foreign trade with beverages and tobacco, crude materials, mineral fuels, lubricants, chemicals and manufactured products. By contrast, the textbook expectations of the negative effect of volatility are validated for the remaining product groups, including machinery, transport equipment, food and animals.

In summary, the results based on disaggregated data clearly demonstrate that the role and effect of exchange rates on Czechia's foreign trade are not definite. One cannot simply assume that the depreciation of Czech koruna will boost exports, reduce imports and, hence, improve the trade balance. It cannot be taken for granted, either, that increased exchange rate volatility automatically reduces foreign trade turnover. This conclusion can be associated with the fact that Czech exporters and importers intensively hedge their foreign trade activities, Czech exports are significantly dependent on imports, and Czech companies are largely owned by foreign investors and belong to multinational corporations. Therefore, product groups and trading partners should be carefully distinguished when considering exchange rate effects on foreign trade. The results obtained can also be taken into account by the Czech National Bank when assessing the potential outcomes of the current exchange rate policy targeted on devalued koruna and allowing interventions on the foreign exchange market.

Publication of this paper was supported by the Student Grant System of Silesian University (project SGS/7/2013). The support is gratefully acknowledged.

\section{References}

[1] ARORA, S., BAHMANI-OSKOOEE, M., GOSWAMI, G. Bilateral J-curve between India and her Trading Partners. Applied Economics. 2003, Vol. 35, Iss. 9, pp. 1037-1041. ISSN 10371041. DOI: $10.1080 / 0003684032000102172$. 
[2] ARRICIA, G.D. Exchange rate Fluctuations and Trade Flows: Evidence from the European Union [online]. Washington D.C.: International Monetary Fund, 1998 [cit. 2014-02-01]. 27 p. (PDF). Available from: http://www.imf.org/ external/pubs/ft/wp/wp98107.pdf.

[3] ARVAS, A.M. Does Real Exchange rate Matter for Emerging Markets' International Trade? A Gravity Model Approach for Turkey. In: Proceedings of First International Conference on Management and Economics. Tirana: Epoka University Research and Application Center, 2008. pp. 77-96.

[4] AUBOIN, M., RUTA, M. The Relationship between Exchange Rates and International Trade: A Literature Review. World Trade Review. 2013, Vol. 12, Iss. 3, pp. 577-605. ISSN 14747456. DOI: $10.1017 / \mathrm{S} 1474745613000025$.

[5] BAEK, J. Does the Exchange Rate Matter to Bilateral Trade between Korea and Japan? Evidence from Commodity Trade Data. Economic Modelling. 2013, Vol. 30, Iss. C, pp. 856-862. ISSN 0264-9993. DOI: 10.1016/j.econmod.2012.11.020. [6] BABECKÁ KUCHARČUKOVÁ, O. The Impact of Exchange Rate Volatility on Trade: Evidence for the Czech Republic [online]. Prague: Charles University, 2014 [cit. 201431-10]. IES Working Papers 03/2014. Available from: http://ies.fsv.cuni.cz/sci/publication/show/ id/5025/lang/cs.

[7] BAHMANI-OSKOOEE, M. Determinants of International Trade Flows: The Case of Developing Countries. Journal of Development Economics. 1986, Vol. 20, Iss. 1, pp. 107-123. ISSN 0304-3878. DOI: 10.1016/03043878(86)90007-6.

[8] BAHMANI-OSKOOEE, $M$. Is there a LongRun Relation between the Trade Balance and the Real Effective Exchange Rate of LDCs? Economics Letters. 1991, Vol. 36, Iss. 4, pp. 403-407. ISSN 0165-1765. DOI: 10.1016/01651765(91)90206-Z.

[9] BAHMANI-OSKOOEE, M., BOLHASSANI, M., HEGERTY, S. The Effects of Currency Fluctuations and Trade Integration on Industry Trade between Canada and Mexico. Research in Economics. 2010, Vol. 64, Iss. 4, pp. 212-223. ISSN 0165-1765. DOI: 10.1016/j. rie.2010.05.001.

[10] BAHMANI-OSKOOEE, M., HARVEY, H., HEGERTY, S. Brazil-US Commodity Trade and the J-Curve. Applied Economics. 2014, Vol. 46, Iss. 1, pp. 1-13. ISSN 0003-6846. DOI: 10.1080/00036846.2013.824548.
[11] BAHMANI-OSKOOEE, M., HEGERTY, S.W. The J-curve and NAFTA: Evidence from Commodity Trade between the U.S. and Mexico. Applied Economics. 2011, Vol. 43, Iss. 13, pp. 1579-1593. ISSN 1466-4283 DOI: 10.1080/00036840802360328.

[12] BAHMANI-OSKOOEE, M., KUTAN, A. The J-curve in the Emerging Economies of Eastern Europe. Applied Economics. 2009, Vol. 41, Iss. 20, pp. 2523-2532. ISSN 1466-4283. DOI: $10.1080 / 00036840701235696$.

[13] BAHMANI-OSKOOEE, M., RATHA, A. The J-Curve:Aliterature Review. Applied Economics. 2004, Vol. 36, Iss.13, pp.1377-1398. ISSN 14664283. DOI: 10.1080/0003684042000201794.

[14] BAHMANI-OSKOOEE, M., RATHA, A. The Bilateral J-Curve: Sweden versus her 17 Major Trading Partners. International Journal of Applied Economics. 2007, Vol. 4, Iss. 1, pp.113. ISSN 1548-0003.

[15] BAHMANI-OSKOOEE, M., WANG, Y. The Impact of Exchange Rate Volatility on Commodity Trade between the U.S. and China. Economic Issues. 2007, Vol. 12, Iss. 1, pp. 31-52. [16] BALDWIN, R., SKUDELNY, F., TAGLIONI, D. Trade Effects of the Euro, Evidence from Sectoral Data [online]. Frankfurt am Main: European Central Bank, 2005 [cit. 2014-02-01]. 55 p. (PDF). Available from: https://www.ecb. europa.eu/pub/pdf/scpwps/ecbwp446.pdf.

[17] CAMPBELL, J., LO, A., MACKINLAY, A. The Econometrics of Financial Markets. Princeton, N.J.: Princeton University Press, 1997. ISBN 978-1400830213.

[18] CLARK, P. Uncertainty, Exchange Rate Risk, and the Level of International Trade. Western Economic Journal. 1973, Vol. 11, Iss. 3, pp. 302-313. ISSN 1465-7295.

[19] ČADEK, V., ROTTOVÁ, H., SAXA, B. Hedge Behaviour of Czech Exporting Firms [online]. Prague: Czech National Bank, 2011 [cit. 2014-02-15]. Working paper series 14. 40 p. (PDF). Available from: http://www.cnb.cz/ en/research/research_publications/cnb_wp/ download/cnbwp_2011_14.pdf.

[20] ENGLE, R., GRAN̄GER, C. Co-Integration and Error Correction: Representation, Estimation, and Testing. Econometrica. 1987, Vol. 55, Iss. 2, pp. 251-276. ISSN 1468-0262.

[21] FELRNINGHAM, B. Where is The Australian J-Curve? Bulletin of Economic Research. 1988, Vol. 40, Iss. 1, pp. 43-56. ISSN 1467-8586. DOI: 10.1111/j.1467-8586.1988. tb00253.x. 
[22] FERTO, I., FOGARASI, J. On Trade Impact of Exchange Rate Volatility and Institutional Quality: The Case of Central European Countries [online]. European Association of Agricultural Economists, 2011. [cit. 2014-0201]. Available from: http://ageconsearch.umn. edu/handle/114351.

[23] HACKER, R., HATEMI, J.A. The Effect of Exchange Rate Changes on Trade Balances in the Short and Long Run. Evidence from German Trade with Transitional Central European Economies. The Economics of Transition. 2004, Vol. 12, Iss. 4, pp. 777-799. ISSN 14680351. DOI: 10.1111/j.0967-0750.2004.00202.x. [24] HOOPER, P., KOHLHAGEN, S. The Effect of Exchange Rate Uncertainty on the Prices and Volume of International Trade. Journal of International Economics. 1978, Vol. 8, Iss. 4, pp. 483-511. ISSN 0022-1996. DOI: 10.1016/00221996(87)90001-8.

[25] HSING, Y. Test of the J-curve for Six Selected New EU Countries. International Journal of Economic Policy in Emerging Economies. 2009, Vol. 2, Iss. 1, pp. 76-85. ISSN 1752-0452. DOI: 10.1504/IJEPEE.2009.022942.

[26] JOHANSEN, S. Likelihood-Based Interference in Cointegrated Vector Autoregressive Models. Oxford: Oxford University Press, 1997. ISBN 978-0198774501. [27] KISS, G.D., SCHUSZTER, T. What are the Differences Between the Currencies of Foreign Exchange Loans? Public Finance Quarterly. 2014, Vol. 59, Iss. 2, pp. 187-206. ISSN 2064-8294.

[28] KUMAR, V. The Real Effects of Exchange Rate Risk on International Trade. Atlanta: Federal Reserve Bank of Atlanta, 1992. Working Paper 92/5.

[29] MAHDAVI, S., SOHRABIAN, A. The Exchange Value of the Dollar and the US Trade Balance: An Empirical Investigation Based on Cointegration and Granger Causality Tests. The Quarterly Review of Economics and Finance. 1993, Vol. 33, Iss. 4, pp. 343-358. ISSN 10629769. DOI: 10.1016/1062-9769(93)90003-3.

[30] NUSAIR, S.A. The J-curve in Transition Economies: An Application of the ARDL Model [online]. New Orleans: Academic and Business Research Institute, 2013 [cit. 2014-02-15]. 31 p. (PDF). Available from: http://www.aabri.com/ NO2013Manuscripts/NO13042.pdf.

[31] OZTURK, I. Exchange Rate Volatility and Trade: A Literature Survey. International Journal of Applied Econometrics and Quantitative Studies. 2006, Vol. 3, Iss. 1, pp. 85-102. ISSN 1988-0081.
[32] PÖYHÖNEN, P. A Tentative Model for the Volume of Trade Between Countries. Weltwirtschaftliches Archiv. 1963, Vol. 90, pp. 93-100. ISSN 1610-2886.

[33] RAJAN, R. Exchange Rate Volatility and Trade Flows - Some New Evidences [online]. Washington D.C.: Intetnational Monetary Fund, 2004 [cit. 2014-02-15]. 131 p. (PDF). Available from: https://www.imf.org/external/np/res/ exrate/2004/eng/051904.pdf.

[34] ROUBÍČKOVÁ, M., RŮČKOVÁ, P. Vliv vlastnictví na využití zdrojů financování v podmínkách České republiky. Acta Academica Karviniensia. 2014, Iss. 2, pp. 130-141. ISSN 1212-415X.

[35] ROSE, A., YELLEN, J. Is there a J-curve? Journal of Monetary Economics. 1989, Vol. 24, Iss. 1, pp. 53-68. ISSN 0304-3932. DOI: 10.1016/0304-3932(89)90016-0.

[36] ŠIMÁKOVÁ, J. Estimation of the J-Curve Effect: The Case of Visegrad Group. In: EBES 2012 Warsaw Conference Proceedings. Istanbul: Teknik Basim Matbaacilik, 2012. pp. 9. [37] ŠIMÁKOVÁ, J. Extended Gravity Model of International Trade: An Empirical Application to Czech Trade Flows. In: STAVÁREK, D., VODOVÁ, P. (Eds.). Proceedings of the 14th International Conference on Finance and Banking. Karviná: Silesian University, School of Business Administration, 2014. pp. 416-421. ISBN 978-80-7248-939-8.

[38] TAGLIONI, D. Exchange Rate Volatility as a Barrier to Trade: New Methodologies and Recent Evidences. Economie Internationale. 2002, Vol. 89 , Iss. 90 , pp. 227-259. ISSN 12408095.

[39] TICHÝ, F. Impact of Accession to EMU on International Trade - Case of the Czech Republic. Prague Economic Papers. 2007, Vol. 16, Iss. 4, pp. 336-346. ISSN 2336-730X.

[40] TINBERGEN, J. Shaping the World Economy: Suggestions for an International Economic Policy. New York: The Twentieth Century Fund, 1962. ISBN 978-1258384302.

[41] TOMANOVÁ, L. Volatility and the Foreign Trade in CEEC. In: Proceedings of the First International Congress on Economics. Ankara: Gazi University, 2013. pp. 649-664.

[42] WILSON, P. Exchange Rates and the Trade Balance for Dynamic Asian Economies: Does the J-curve Exist for Singapore, Malaysia and Korea? Open Economies Review. 2001, Vol. 12, Iss. 4, pp. 389-413. ISSN 1573-708X. DOI: $10.1023 / A: 1017982901034$. 
Ing. Jana Šimáková, Ph.D.

Silesian University in Opava

School of Business Administration in Karviná

Department of Finance and Accounting simakova@opf.slu.cz prof. Ing. Daniel Stavárek, Ph.D.

Silesian University in Opava

School of Business Administration in Karviná

Department of Finance and Accounting stavarek@opf.slu.cz 


\title{
THE EFFECT OF THE EXCHANGE RATE ON INDUSTRY-LEVEL TRADE FLOWS IN CZECHIA
}

\author{
Jana Šimáková, Daniel Stavárek
}

This paper is the first study to use the disaggregated data of the Czech foreign trade to examine the effect of exchange rate levels and volatility on trade flows. Czechia is the appropriate economy to study this phenomenon because it is heavily involved in foreign trade predominantly owned by international investors and has been applying a floating exchange rate arrangement for many years. We analyze the period from 1993 to 2013 and disaggregate the data according to trading partner and product category. While the effect of exchange rate level is examined by a modified vector error correction model the effect of exchange rate volatility is analyzed through an extended gravity model. The detailed results obtained from empirical estimations clearly show that the relationship between exchange rates and foreign trade in Czechia does not completely correspond with the theoretical assumptions. We revealed that domestic currency depreciation worsens in the long-term trade balance in substantial parts of the Czech foreign trade, such as in the trade of machinery and transport equipment with Germany, Austria and France. The classical J-curve effect was confirmed only for the trading of beverages and tobacco with Italy and for the trading of manufactured goods with Slovakia. We also found that an increased exchange rate volatility does not necessarily reduce foreign trade turnover, as the results for crude materials, fuels, chemical and manufactured products indicate. By contrast, the theoretical expectation of negative impact of volatility was validated for machinery, transport equipment, food and animals. Therefore, although Czechia is a small, open economy, the exchange rate effects on foreign trade significantly differ in magnitude and direction across the trading partners and product groups.

Key Words: Exchange rate, industry-level data, trade balance, cointegration, vector error correction model, gravity model.

JEL Classification: F14, F31.

DOI: 10.15240/tul/001/2015-4-011 